European Planning Studies, Vol. 9, No. 1, 2001

\title{
Industry Glusters in Ireland: An Application of Porter's Model of National Competitive Advantage to Three Sectors
}

\author{
PAULA CLANCY, EOIN O'MALLEY, LARRY O'CONNELL and \\ CHRIS VAN EGERAAT
}

[Paper first received, April 1999; in final form, October 1999]

\begin{abstract}
This paper examines the importance of industrial clusters, and the relevance of Porter's diamond model, in the context of the small open economy of Ireland. It analyses the experience of three relatively successful Irish indigenous sectors and it considers to what extent have clusters of related or connected industries been important in accounting for the degree of success attained in Ireland. We do not find evidence of well-developed clusters of the type described by Porter, and our study provides support for some previous critiques of Porter's model. It is concluded that Irish industrial policy does not need to be focused strongly on developing the type of industry clusters described in Porter's model. At the same time, different elements of Porter's model do prove to be relevant and we find that companies in Ireland benefit from being part of some form of wider grouping of connected or related companies and industries, although these groupings can differ from Porter's clusters in significant respects.
\end{abstract}

\section{Introduction}

A good deal of discussion in the 1990s concerning industrial policy in Ireland has focused on the proposition that a competitive and successful industrial performance requires the development of competitive advantage in clusters of interlinked industries or sectors. This discussion reflects the insights of international researchers, particularly Porter (1990). It also influenced a major review of Irish industrial policy in the early 1990s (the 'Culliton report'), which recommended that policy should aim to develop groups or clusters of related industries, building on sources of national competitive advantage (Industrial Policy Review Group, 1992, pp. 73-74).

In order to explore further the implications of this issue for Ireland, the National Economic and Social Council (NESG) subsequently commissioned us to undertake a study to

Chris Van Egeraat, The Business School, Dublin City University, Dublin 9, Ireland. Tel: + 353-1-4542044; e-mail: cvane@tinet.ie.

Paula Clancy, Dun Laoghaire Institute of Art, Design and Technology, Dublin, Ireland.

Eoin O'Malley, Economic and Social Research Institute, Dublin, Ireland.

Larry O'Connell, The Graduate School of Business, University College Dublin, Dublin, Ireland. 
examine the importance of industrial clusters, and the relevance of Porter's diamond model, in the Irish context. This study analysed the experience of three relatively successful Irish sectors and it considered the extent to which the presence of clusters of related or connected industries has been important in accounting for the degree of competitive success attained in each case. Separate reports on these three case studies have been published by NESC (O’Connell et al., 1997; Clancy \& Twomey, 1997; O’Gorman et al., 1997). This article draws together and integrates the principal findings from these three case studies and it presents overall conclusions together with a discussion of the policy implications.

To set the article in context, we first provide a brief review of some of the principal features of recent Irish industrial development. We then outline Porter's model as well as certain critiques of his theory which are of particular relevance. The findings of the research are analysed next under three main headings: competitive performance, the role of Porter's determinants of competitive advantage, and the role of clustering. Finally, we present our conclusions and discuss the policy implications.

\section{Context: Irish Industrial Development and Industrial Policy}

A prominent characteristic of industrial growth in Ireland after the end of the 1950s was that the main source of growth was new investment by foreign-owned multinational companies which chose Ireland as a site in which to produce for export markets. From the beginning, such export-oriented foreign investment was motivated mainly by tax concessions, grants and relatively low wage costs (by Western European standards). Later, after Ireland joined the EC in 1973, there was also the further significant attraction of assured access to the large EC market. An additional enticement for many overseas investors since the 1970s has been the fact that the Irish education system managed to produce a good supply of people with certain key types of qualifications at times when these were in strong demand for some rapidly growing industries internationally, e.g. electronics, pharmaceuticals and, more recently, software.

Although the export-oriented foreign-owned firms made the major contribution to industrial growth in the 1960s and 1970s, employment in foreign-owned manufacturing peaked in 1980 and it then declined by $11 \%$ over the period 1980-1987. Taken together with some concern about issues such as limited purchasing linkages and withdrawals of profits from the country, this led to a growing perception that heavy reliance on foreign-owned firms was no longer, on its own, an adequate strategy for industrial development.

There was quite strong industrial growth in Ireland in the 1960s and 1970s, but native Irish-owned or indigenous industry had not fared very well. Indigenous industry did not have a great deal of success in developing exports, while at the same time it was quite rapidly losing domestic market share to competing imports as the protectionist measures employed in the 1930s-1950s were dismantled. In this context, there was no employment growth in indigenous industry between the mid-1960s and the end of the 1970s. Then in the period 1980-1988 its employment fell sharply by $22 \%$, as a result of continuing heavy dependence on the domestic market, a continuing rise in competing imports, and a much weaker trend in domestic demand. Thus, until the mid-1980s, indigenous industry had a poor competitive record under free trade conditions (see O’Malley, 1989, for a more detailed account of developments until that time).

During the 1980s, official policy documents began to focus more explicitly on the objective of developing Irish indigenous industry (without by any means neglecting foreign-owned industry). Policy statements since the White Paper on Industrial Policy (1984) said that policy towards indigenous industry should be somewhat more selective, in the sense of aiming to develop larger and stronger firms by building on those with a reasonable track record, rather 
than assisting a great many firms indiscriminately. ${ }^{1}$ It was also intended to concentrate State supports and incentives more on correcting specific areas of weakness which would be common in indigenous firms, such as technological capability, export marketing, and management skills (Industrial Policy, 1984, Chapters 1 and 5; Department of Industry and Commerce, 1987, Chapter 2). Another notable theme in statements of industrial policy objectives after the early 1980s was the aim of strengthening the degree of integration of foreign-owned enterprises into the Irish economy.

From the mid-1980s, quite a number of policy changes were introduced which were consistent with these stated objectives (O'Malley et al., 1992). In 1992, the Industrial Policy Review Group (1992, p. 67) recognized that greater efforts had been undertaken by then to promote indigenous industry, but the Group called for a still more decisive shift in the focus of policy towards developing indigenous industry, and this objective has since been re-emphasized.

Since about 1987, industry in Ireland has had a strong growth performance, both by comparison with trends earlier in the 1980s and by comparison with trends in other industrial countries. The particularly rapid growth of the Irish economy, which led to the coining of the term 'the Celtic Tiger', owed a great deal to the industrial sector which had an average growth rate of $10 \%$ per year after 1987 . A substantial increase in foreign direct investment was a large part of the reason for this. Between 1987 and 1996, foreign-owned firms increased their share of Irish manufacturing employment from $43 \%$ to $47 \%$ and they increased their share of manufacturing output from $52 \%$ to $66 \%$.

However, there was also a very significant improvement in Irish indigenous industry. Since 1987, the rate of growth of output of indigenous industry has averaged about $4 \%$ per year, which was approximately twice as high as the industrial growth rate of the EU or OECD. Employment in indigenous industry has been on a rising trend since 1988, while manufacturing employment has been declining significantly in the EU and in most other major OECD economies. And the exports of indigenous industry have been growing faster than the manufacturing exports of the EU or OECD. A number of other features combine to confirm that this was a genuinely strong competitive performance, rather than simply a response to favourable demand conditions in the rapidly growing Irish economy. This growth in Irish indigenous industry has been spread across a wide range of sectors, with employment growth occurring in about three-quarters of all sectors (O'Malley, 1998). While a number of favourable influences contributed to this relatively strong performance, it appears that the policies introduced since the mid-1980s to give a new impetus to the development of the indigenous sector have been meeting with some success.

This article explores the role of industry clusters, as defined by Porter (1990), in sustaining competitive advantage in Irish indigenous industry, as well as the applicability of Porter's clustering model in the Irish context. In view of the importance of Porter's diamond model in our study, the next section briefly summarizes the principal features of the model as well as certain critiques of the model which are particularly relevant.

\section{Porter's Diamond Model}

Porter's model is now well established (Porter, 1990, 1998) and it will be only briefly summarized here. His thesis is that to understand why nations gain competitive advantage the focus should be on particular competitive industries within the nation. For national competitive advantage to occur, however, it is not sufficient to have a number of unconnected successful industries; rather it is necessary to develop clusters of indigenous or 'home-base' industries which are competitive and are linked together through a range of common, supporting conditions. According to Porter the competitive advantage of an industry derives 
from the national 'diamond', i.e. four different determinants of competitive advantage which are created within the home base of the nation state: factor conditions, demand conditions, related and supporting industries, and firm strategy, structure and rivalry. He also identifies two residual influences: government and chance events.

The operational concept in Porter's model is not cluster, which is no more than a localized concentration of linked sectors or industries, but clustering - the particular process that leads to the development of clusters. The conditions which bring about industry clustering grow directly out of the determinants of competitive advantage and are a manifestation of their systemic character. Thus, another key feature of the model is that the determinants operate as a system. Each determinant affects the others. In this clustering process one competitive industry helps to develop and to support another in a mutually reinforcing process.

The important role of the interaction among the determinants means that advantage in an industry depends in part on how effectively the interactions work in a nation. Thus, underlying the operation of the national diamond and the phenomenon of clustering, is the exchange and flow of information about needs, techniques, and technology. Porter emphasizes the importance of geographic concentration, since proximity greatly facilitates the flow of this information central to the capability to innovate and to upgrade competitive advantage. Apart from spatial proximity, the containment of a diamond within national borders will also bring cultural and social proximity, further facilitating the flow of information.

\subsection{Critiques of Porter}

The purpose of our research was to explore the relevance of Porter's cluster concept to the development of the competitive advantage of Irish industries. In doing so we took account of the significant body of critical work in relation to his model. Of particular relevance to the case of Ireland were those critiques concerning the related issues of geographic proximity, the 'home base' and the role of foreign direct investment and these will be briefly reviewed here. ${ }^{2}$

An issue of considerable importance to a small peripheral country, such as Ireland, is that aspect of the model which lays stress on the importance of the national environment as the source of competitive advantage and the related emphasis on the importance of geographic proximity of firms, their suppliers and buyers as well as related industries. This notion of the importance of geography as a critical dimension of firm organization and competitiveness is not new and finds resonance in the equally vast literature on industrial districts and 'new high volume production regions' (Hudson, 1997).

However, as regards the geographical configuration of production systems, the critics argue that the importance of geographic proximity may be partial (Penttinen, 1994). There also appears in many industries to be some tendency towards dispersal as the sector develops (Dalum et al., 1991). The relevant geographical scale of production systems differs by industry and some are bound to cross national borders (Jacobs, 1995). As a matter of fact, Van Grunsven and Van Egeraat (1999), studying the electronics cluster in Singapore, suggest that the cross-border expansion of the electronics complex has been a necessary element of the upgrading process, facilitating the further development of this (cross-border) cluster. When considering the relevance of their findings for the Celtic peripheral economies, the authors suggest that it might not be feasible in a small open economy like Ireland's to develop broad and deep (or vertically complete) clusters within the national territory. In a recent reiteration of his ideas, Porter himself more explicitly assents to this idea of border-crossing clusters (Porter, 1998).

As regards the sources of competitive advantage, O'Donnell (1998) presents a more fundamental critique of Porter's contention that firms mainly derive competitive advantage from characteristics of the 'home base'. He questions Porter's ideas that the process of creating 
skills and the important influences on the rate of improvement and innovation are intensely local and that many external economies do not cross national boundaries easily. According to O'Donnell it seems possible that some economies, and societies, are so open that purely local processes of innovation are limited and many external economies do, in fact, cross national boundaries easily. This implies that innovation efforts and external economies are not retained within the national economy and, futhermore, that locally-owned firms are not "constrained by the paucity of local innovation processes" (O'Donnell, 1998, p. 53).

In the context of small open economies such as Ireland, the relative importance of domestic demand conditions and domestic rivalry provokes particularly divergent views. It has been argued that Porter's model does not work very well for smaller open economies (SOEs) such as Canada, Finland, Austria, New Zealand and Ireland (Rugman \& D'Cruz, 1993; Bellak \& Weiss, 1993; O’Donnellan, 1994; O’Donnell, 1997). The domestic market can be too small to be the main or even an important market for some industries. Hence, it is argued, domestic demand compared to the influence of relevant foreign demand often has rather little influence on many producers in small countries and this reduces its impact as a major determinant of competitive advantage for industries in small countries. Related to this is the argument that, in many cases, small countries cannot support the number of firms necessary for domestic rivalry and that firms in these countries instead benefit from competition with firms in other countries.

The relative importance of the home base is related to another contested element of Porter's model - the role of multinational enterprises (MNEs). Porter has been widely criticized for excluding foreign-owned MNEs as contributors to the competitive advantage of advanced economies (unless they "become part of the host country diamond"). Although Porter (1990, p. 679), in a passage referring to developing countries, acknowledges that foreign MNEs can occasionally serve to 'seed' a cluster, the main thrust of his theory undoubtedly puts the major emphasis on indigenous home-base industries as having the potential to be the important participants in a cluster. This issue concerning the influence of foreign-owned MNEs is particularly problematic in the Irish case since inward foreign direct investment represents a very large segment of Irish economic activity. O'Donnell (1997) has suggested that, due to the presence of foreign subsidiaries, Irish business is adopting new technologies and skills, and is undergoing a profound transformation of its organizational capability.

Direct production linkages between foreign subsidiaries in Ireland were slow to develop, but recent evidence suggests that the multinational subsidiaries in the electronics industry are becoming increasingly 'embedded' in the Irish production structure, ${ }^{3}$ which is not necessarily the same as the indigenous production structure. Indeed, there are increasing examples of multinational subsidiaries creating their own 'clusters of foreign-owned activity' in host economies (Morris, 1989; Peck, 1990; Dunning, 1992; Cooke, 1995; Van Grunsven \& Van Egeraat, 1999).

\section{Competitive Performance of the Three Selected Sectors}

Our study aimed to select three relatively competitive Irish indigenous sectors and then to examine to what extent has the presence of clusters of related or connected industries been important in accounting for the degree of competitive success attained in each case. Of the three case studies, one was to be in manufacturing, one was to be in internationally traded services, and the other was to be a sector which is influenced to an appreciable degree by interactions with foreign-owned companies in Ireland.

In order to select three sectors for these case studies, we first attempted to identify all sectors in which Irish indigenous industry could be regarded as relatively competitive and successful. ${ }^{4}$ As in Porter's (1990) approach, we examined the international trade performance 
of each industry, identifying those which had a relatively large share of world exports in their category, compared to Ireland's overall share of total world exports, as well as a positive balance of trade. We also took account of other indicators of a successful performance such as employment growth, profitability, rate of growth of exports, rate of change in share of world exports, and rate of change in the balance of trade.

Perhaps not surprisingly, very many of the sectors which emerged as relatively competitive and successful turned out to be predominantly foreign-owned. ${ }^{5}$ What was rather more surprising was that it actually proved to be very difficult to find clear and convincing examples of strong and competitive indigenous sectors. In most cases, those which appeared strong on one or two indicators looked weak in terms of other indicators. For example, some sectors had a relatively large share of world exports, but also a declining trend in exports or employment over time. Or others had a strong growth trend, but still had only a relatively small share of world exports. There were also a number of prominent cases which had generally positive indicators of a competitive and successful performance, but this depended greatly on just one large company. It would be difficult, therefore, to maintain that these are clear-cut examples of strong indigenous industries or sectors.

Thus, despite the fact that there has been a relatively good performance by Irish indigenous industry over the past decade or so, it remains difficult to identify convincing examples of strong and competitive indigenous sectors. This is quite an important point because such individual indigenous sectors are the basic building blocks of Porter's concept of 'clusters'. If Ireland has few such sectors, this in itself suggests that it is doubtful whether there can be significant examples of clusters of the type which Porter suggests are generally required for competitive success.

Although it was difficult to find clear-cut cases of competitive indigenous sectors, we chose for our case studies three sectors which seemed to be among the best examples available. These were dairy products for the manufacturing case study, the popular music industry for the internationally traded services case study, and the indigenous software industry for the case study of a sector with significant contact or interactions with foreign multinationals in Ireland.

As regards competitive performance, the indigenous software industry is the most clearly successful and competitive of the three case studies. Growth rates for the number of companies, employment and sales have all been exceptionally high, while exports have grown even faster than sales. The industry's sales and exports have been growing a good deal faster than international demand in the 1990s, indicating that it has been gaining a quite rapidly increasing market share and can therefore be regarded as internationally competitive. ${ }^{6}$

The Irish dairy industry has a good performance record, particularly in terms of exports. It performed strongly during the 1980s and up to the mid-1990s. Trade statistics demonstrate that Ireland has a comparative advantage in dairy products and a 'basket' of cross-country measures provides us with evidence of relative international competitive performance in the sector. In summary, Irish growth rates have been among the highest in Europe, as has productivity and the level of investment. Profitability has also improved strongly. At the same time employment has decreased but this is broadly in line with trends elsewhere. The value added of Irish companies remains somewhat below that of competitors. However, despite the strong overall performance, it is by no means clear that the industry can really be described as competitive. To a very important degree, it operates in a regulated and supported environment which is not subject to the full normal forces of competition. Porter's model, however - with its emphasis on the importance of clusters for competitive success - refers to the determinants of substantial and sustained success in an internationally competitive environment.

The Irish popular music industry turned out to be really only successful in a limited sense - the major Irish artists, rather than the whole industry, are relatively competitive. The 
available information indicates that Ireland has achieved considerable comparative success in terms of a number of internationally successful artists which is quite disproportionate to the size of the country's population. Although industry informants suggest that most are Irish residents it is difficult to estimate the economic contribution of these artists to Ireland. Certainly, since the majority signs to international record companies located in either the UK or the US, most of the financial benefits accrue to these economies. Stripping out the activities of these artists the picture of the music industry is less impressive. In terms of its structure the Irish recording industry is dominated by a handful of foreign-owned global record companies. Indigenous enterprises are small scale and very few are either economically viable or can be regarded as competitive in the sense in which Porter (1990) would use the term. The domestic market for recorded music is dominated by imports.

To conclude on competitive performance, Irish indigenous industry simply does not provide many clear and convincing examples of sectors which are successful and competitive, despite the relatively strong performance by Irish indigenous industry as a whole over the past decade. Our three case study sectors seemed to be among the best examples available, but two of them can scarcely be regarded as clearly competitive industries. This presents us with a significant analytical problem when it comes to considering our conclusions on the role of clusters in accounting for their degree of competitive success. We return to address this issue in the section on Conclusions and Policy Implications.

\section{The Role of the Determinants of Competitive Advantage and Clustering}

In this section we summarize the contribution of Porter's four determinants of competitive advantage to the performance of the three case study industries, and this is followed by an assessment of the significance of the clustering concept.

\subsection{Role of Determinants}

The case studies indicated that many aspects of Porter's suggested determinants of competitive advantage have a significant influence, although there are also some important divergences from Porter's model. Here we outline first the positive influences exerted by the four determinants, and then we summarize the differences from the model.

In the case of the indigenous software industry, factor conditions have clearly been important for its competitive advantage, particularly with respect to the availability and quality of the skilled labour force. The industry requires substantial numbers of third-level graduate staff as shown by the fact that, in a large majority of indigenous software companies, at least $70 \%$ of staff have third-level qualifications. Ireland has had a relatively good supply of relevant graduates, ranking fifth among OECD countries in terms of the number of 'mathematics and computing' degrees awarded in the early 1990s relative to size of population (derived from OECD, 1995, Tables R12 and R15). For the most part, the education system produced sufficient numbers of computer and related graduates to keep up with the rapid growth in demand, at least until the mid-1990s (Clarke, 1995). This was in contrast to many other European countries (Coe, 1997). The quality of Irish graduates for the software industry is considered to be relatively high (Coe, 1997). For our case study on the industry, we interviewed owners or managers of indigenous companies accounting for about one-third of indigenous employment in the industry. Three-fifths of these felt that Irish graduates were of better quality than US or UK graduates, while the remainder felt that they were about the same. Apart from the education system, other 'factor creating mechanisms' help to develop and sustain the skilled labour force, including companies' own relatively heavy investment in staff development, the acquisition of specialized expertise on the job, and advisory and 
training assistance from State agencies. In addition, financial assistance from State agencies has been important for many companies. In the company interviews for our case study, about two-fifths of respondents said that State financial assistance had been important or very important for their company's development.

In various ways, domestic demand conditions have had a positive influence on developing the competitive advantage of most indigenous software firms. For example, interaction with sophisticated customers has helped companies to develop new or improved software products and services which are usually specialized for specific market segments. A large majority of the indigenous software companies we interviewed said the companies' interactions with their customers in Ireland have been beneficial for the development of their businesses. When they were asked specifically about the role of foreign-owned MNEs in Ireland as customers, a substantial majority agreed that the MNEs have relatively demanding standards and that their influence as purchasers of software tended to push their Irish suppliers to achieve high standards and hence to develop competitive advantage. Although domestic demand conditions have been a significant influence for most of the indigenous software industry, there is an appreciable minority of companies for whom domestic demand conditions are of little or no relevance because they export all or nearly all of their output.

As regards 'related' industries, about two-thirds of the indigenous software companies that were interviewed said that there are significant related sectors which have helped to develop labour skills and experience for the industry. These related sectors include, most notably, the foreign-owned branch of the software industry in Ireland and the foreign MNE-dominated computer and telecommunications equipment sectors. In addition, a substantial minority of the companies interviewed have had business relationships or alliances with foreign MNEs in Ireland, typically with MNEs in computer hardware or software, in activities such as distributing or marketing of their products. Irish software entrepreneurs have also very commonly gained experience working in foreign-owned MNEs. About one-third of the founding entrepreneurs of the companies interviewed had been working in foreign-owned MNEs in Ireland immediately prior to start-up, and about two-thirds of them had gained experience working in a foreign MNE in Ireland at some stage in their careers.

Finally, in the area of strategy, structure and rivalry, most indigenous software companies have appropriate strategies of specializing in market niches. Most of them also invest heavily in staff training and development and in new product development compared to other Irish sectors. Local competition and rivalry seems to have a positive influence on many companies' competitiveness. Three-fifths of the indigenous software companies interviewed said that they encounter strong competition in the Irish market from other firms located in Ireland, and most of these agreed that this has the effect of increasing Irish companies' international competitiveness. Nevertheless, a large minority of firms do not encounter significant local competition in the Irish market, either because they sell very little or nothing in Ireland or because they are shielded by their exceptionally specialized niche positions.

In the case of the dairy industry, Ireland has a reasonable endowment of factor conditions. The level of operational skills, the supply of graduates, technical expertise, and a healthy national image were all identified as relatively strong elements. The managers of 11 dairy processing companies interviewed for this research all agree that the skill levels at operational level are excellent and the companies have no difficulty in obtaining sufficient numbers of technical staff. The Irish education system provides an ample supply of technical and research personnel. The department of Food Science, University College Cork (UCG), has always had a strong orientation towards the dairy industry. In 1996 alone, 91 B.Sc. graduates and 26 postgraduates graduated from this department, against a pool of $195 \mathrm{R} \& \mathrm{D}$ staff employed by the 13 biggest Irish dairy companies in 1993 (UCG and Forfas, unpublished data). As regards the local knowledge base, a recent survey of European ingredient buyers found that Irish dairy 
companies are perceived to be at least as technically competent as their foreign competitors (PA Consulting Group, 1996) and the interviewees in our research named, inter alia, UCC and Moorepark Technology as high-standing 'knowledge creating mechanisms'. Finally, the interviewees highlighted the image of Ireland as 'green and healthy' as a positive factor in the development of strong international brands (e.g. Kerrygold).

With respect to home demand conditions, the sophisticated and demanding Irish multiples and the foreign-owned MNE customers located in Ireland have had a positive influence on the standards of the Irish dairy processors. Managers of the biggest three dairy companies stated that supplying the Irish multiples meant that they had to upgrade their standards across various functions - an experience that has been useful when entering the UK retail market. However, the major Irish multiples have had an even greater impact on cost efficiency. With $65 \%$ of the retail market controlled by the top-three players in 1994, the Irish retail sector is one of the most concentrated in Europe (ABN.AMRO, 1996; Goodbody Stockbrokers, 1995). All dairy company interviewees were of the opinion that this has generated very strong pressure to reduce prices. The resulting drive for cost efficiency has undoubtedly helped the companies in international competition. As regards MNE customers located in Ireland, all but one interviewee agreed they had learned from the standards and systems employed by these MNEs, an experience that helped them in international markets.

As regards related and supporting industries the Irish dairy farmers are competitive producers of milk, the single most important input of the processors. Even allowing for the lower fat and protein content of the milk supply, the milk price paid by Irish processors is lower than that paid by their main European competitors (ABN.AMRO, 1996). Although this advantage is partly offset by a highly seasonal supply, on balance the data suggest that Irish farmers, compared to farmers in most other European countries, are competitive producers.

Finally, within the existing regulatory framework of the Common Agricultural Policy, the structures, strategy and rivalry of the Irish dairy industry has had a positive impact on competitiveness. With respect to structure, processors have adopted innovative governance structures, such as the co-op/plc structure. Four of the five major players adopted a hybrid co-op/plc structure. This provided a means by which many of the problems associated with the cooperative structure and vertical ownership, as experienced by some of their main European competitors, could be overcome (Harte, 1995). Competition in the Irish marketplace has been largely confined to competition for raw milk supplies. In the 1980s, the various companies within the fragmented Irish dairy processing industry competed aggressively for milk supplies by offering higher rewards to the farmers. A number of interviewees supported the view that this rivalry gave an impetus to increasing processing efficiencies as producers vigorously tried to reduce costs. This, in turn, facilitated the international acquisition strategies. Furthermore, the rivalry reduced take-over opportunities in Ireland, thereby forcing companies to look beyond Ireland. In parallel, we found evidence of cooperation. Cooperation is most developed in the area of marketing where processors have been able to increase their marketing scale and bargaining power through the operation of the Irish Dairy Board. As regards R\&D, all managers acknowledged the important role of indirect collaboration through Moorepark Technology. ${ }^{7}$ Direct cooperation is informal and mostly linked to production/ engineering 'problem solving'. Although helpful, managers did not believe that this had a significant impact on innovation and competitiveness.

In the case of the music industry, as stated earlier this sector can not really be regarded as competitive, and few of Porter's suggested determinants of competitive advantage are at work. Only the major Irish artists are relatively competitive. A number of factor conditions have been identified as contributing to the success of these artists. Probably the most important of these is the fact that Ireland is primarily English speaking, while English is the principal language of global popular music. In the late 1970s, a detailed analysis of the 
Billboard charts of top selling records around the world found that songs with lyrics in English dominated the charts in most countries (Negus, 1992). More recently, the Anglophone 'bloc' of the UK, Ireland, the US and Canada had 66 of the top 100 albums and 42 of the top 100 singles in the EU in 1995 (Laing, 1996). In countries where English is the main language hit records in any other language are almost non-existent. Furthermore, in countries where English is not the primary language, a large proportion of the music sold has English lyrics, thus providing a large global market open to artists from the English-speaking world (Negus, 1992).

There is also a widespread consensus among music industry informants that Ireland has an established 'brand reputation' as an attractive location and as a source of successful artists. This provides benefits to the country as a preferred location for international music industry players. The reputation of Ireland also provides access to international markets in two ways: audiences are more receptive to Irish artists, and important gatekeepers within the international music industry are more open to Irish artists. Ireland's brand name as a location derives from a number of interrelated characteristics. These include cultural traits of friendliness combined with respect for privacy, a perception of Ireland as a fashionable centre for all aspects of the entertainment industries, the country's reputation as being particularly rich in the arts including literature for example, the perceived 'Celtic' influence on music, the image of Ireland as a non-imperialist State, Ireland's cultural position - including its language somewhere between American and British musical culture, and Ireland's standing as a tax-friendly environment for composers. Apart from the brand 'reputation' or 'image', there is also a view among some music industry informants that Ireland is comparatively rich in both the size and quality of its pool of musical artists, from whom internationally successful popular musicians can emerge. However, this view is contested by others. In the absence of hard data, industry informants vary on whether Ireland does have a significantly greater proportion of popular musicians than is the case in other countries.

Domestic demand conditions also have a positive impact on the Irish music industry. The nature of domestic demand - being largely similar to the type of demand which is dominant in the UK, the US and hence in the international market - probably has been significant in helping to foster a type of artist who can appeal to the international market.

Although the case studies indicate that various aspects of Porter's suggested determinants of competitive advantage are significant, there are a number of important divergences from Porter's model. First, domestic demand conditions are not always a key influence and can sometimes be replaced by overseas demand. Some Irish firms or parts of sectors can have interactions with overseas customers which are influential or beneficial, sometimes more so than their links to domestic demand. In fact, some such companies can be successful while having little or no contact with domestic demand. Second, strong domestic rivalry is not central to some parts of the industries which we studied. For some companies a degree of competition or rivalry from competitors located abroad can be more influential than domestic rivalry. And some such Irish companies can be competitive and successful while experiencing little or no domestic rivalry. Third, the importance of domestic suppliers is limited in all three cases. And fourth, foreign-owned MNEs in Ireland, rather than Irish indigenous industries, at times play key roles as related and supporting industries or as customer industries. We elaborate here on the first three of these four points, while the fourth point concerning foreign MNEs in Ireland comes up when considering the role of clustering below.

In the dairy industry it is possible to identify some significant influence of domestic demand on competitive advantage. However, there are two important caveats to this general finding. First, the effect of domestic demand on the product portfolio of the Irish dairy companies tends to be overshadowed by the external demand conditions created by the Common Agricultural Policy (CAP). Second, many companies in the dairy industry are fostering 
intensive and beneficial relations with retail and industrial customers located abroad, relations which can be as significant as links with customers in Ireland. In the music industry, the nature of domestic demand probably has been significant in helping to foster artists with international appeal. However, it is also the case that internationally successful artists commonly sell their services to companies located abroad rather than in Ireland, and they quite commonly experience their first significant success in overseas markets. In the indigenous software industry, domestic demand has had an influence which is undoubtedly disproportionate to its relatively small size. Nevertheless, there is a sizeable minority of software firms for whom domestic demand has been of little or no relevance and who deal exclusively or almost exclusively with customers abroad. Many of these software companies are successful.

The influence of domestic rivaly is manifest in the dairy industry where there is vigorous competition between firms, but this competition is mainly between firms within limited geographic regions and it is mainly focused on competition for supplies of milk. On the demand side, although all the dairy companies stated that competition for market share in the Irish market place is very intense, most companies were in agreement that competition in foreign markets is even more intense. Neither is strong domestic rivalry an important influence in the music industry. In the software industry, however, rivalry among domestic firms has an importance which is disproportionate to the size of the local Irish industry. Nevertheless, there is a substantial minority of software firms for whom domestic rivalry has been of little or no relevance and whose real competitors are located abroad. Many of these Irish firms are competitive and successful.

Domestic suppliers have a limited effect on competitive advantage in all three industries. For the dairy industry, the role of domestic suppliers is minimal apart from the role played by dairy farmers as suppliers of milk. In the music industry, most internationally successful artists avail of supplier inputs from abroad and the important supplier industries in Ireland are relatively weak. And no Irish suppliers to the indigenous software industry have a significant impact on its competitive success, although this is more a reflection of the nature of the industry rather than a particular weakness on the supplier side in Ireland.

\subsection{The Role of Clustering}

Having identified the role of the four determinants of competitive advantage, we now need to consider whether the three case study industries can be seen as forming part of clusters of connected competitive industries, in Porter's sense of the term, and we need to consider the significance of Porter's clustering concept. We first outline the incidence of clustering involving each of the three industries and then we draw overall conclusions on the role of clustering.

The indigenous software industry can be regarded as part of a larger grouping of industries which has most of the important characteristics of a cluster. Figure 1 shows the structure of industries and organizations in this 'cluster'. At its core are a large number of indigenous software firms many of which are internationally competitive. These are highly concentrated geographically with two-thirds of them being located in the Dublin area, while there are also smaller concentrations in Cork, Limerick/Clare and Galway. There are no significant Irish supplier industries for the indigenous software sector in the cluster. The Irish customer industries include a wide range of sectors but some of them stand out as being particularly influential. These include foreign-owned MNEs in the 'process flow' industries (meaning pharmaceuticals, chemicals, drinks, dairy products, etc.), in software, computer hardware, telecommunications equipment and financial services, as well as indigenous firms in the process flow industries and financial services. These sectors are generally internationally competitive. There are also some significant related industries, particularly the foreign-owned branch of the software sector and the foreign MNE-dominated computer hardware and 


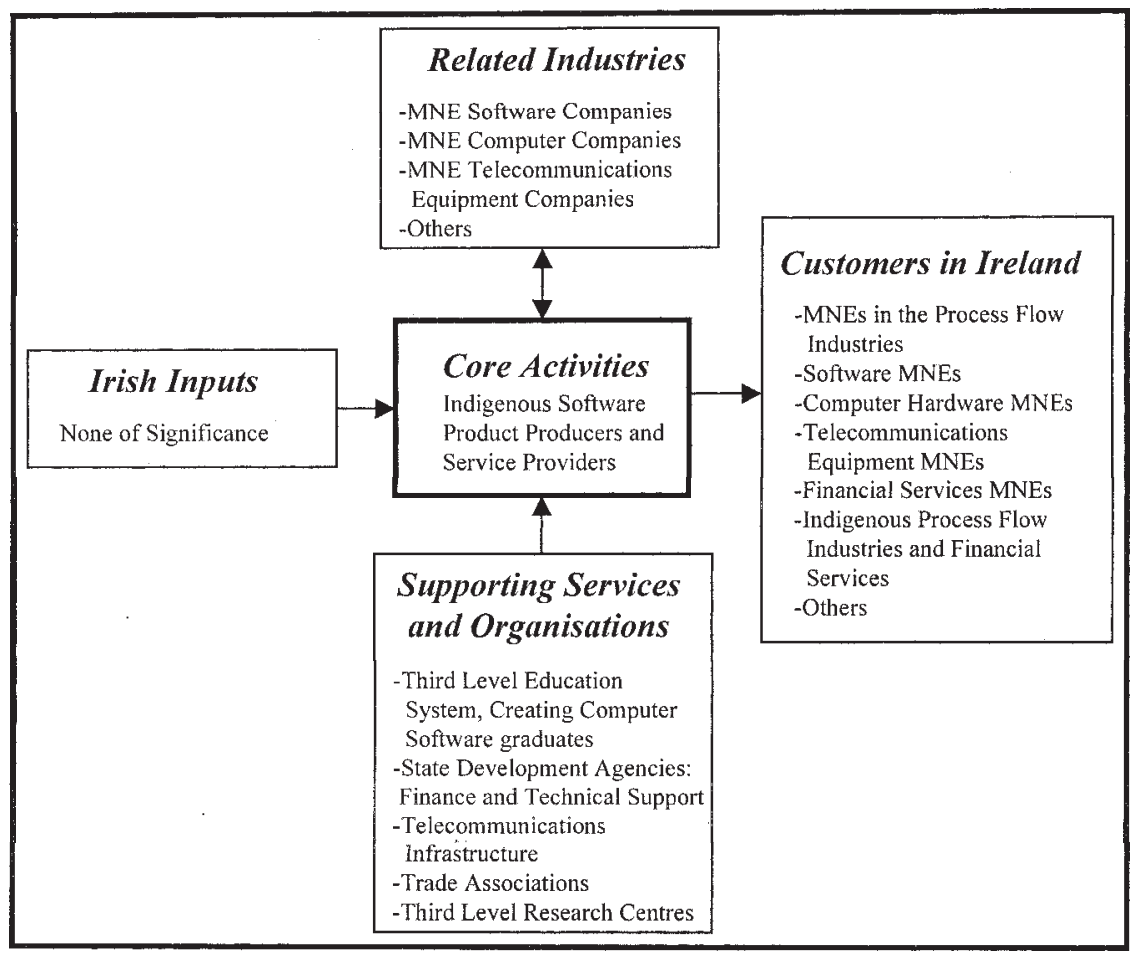

Figure 1. Extended linkages chart of the indigenous software industry.

telecommunications equipment sectors. Finally, there is a range of supporting services and organizations. It is noticeable that the other industries in this cluster consist predominantly of foreign-owned MNEs - a feature which differs from the mainly indigenous industry clusters described by Porter as the general case.

Although there are some reservations about describing this as a mature and fully-formed cluster of the sort which Porter describes, it has most of its significant features and these could develop and strengthen further. In line with Porter, we found evidence of indigenous software companies benefiting from the systemic effects of this grouping of connected and related industries. Thus, there is a rich degree of beneficial interaction between companies within the indigenous software sector, as well as between the sector and other connected or related industries in Ireland. The individual Irish-owned software companies help to develop and then draw from a common pool of skilled labour. Many founding entrepreneurs of new companies come from employment in other indigenous software firms. Competition between Irish software firms is commonly a significant factor which improves competitiveness. And cooperation or social interaction between companies is often quite important. Looking beyond the industry itself, the principal customer sectors and related industries in Ireland have been influential for its competitive advantage. In fact, the principal related industries are included among the more influential customer industries. Consequently these industries have influenced domestic demand conditions while they have also helped to develop relevant labour skills or to give experience to Irish software entrepreneurs, or they have engaged in cooperation with indigenous software firms. The presence of this whole group of industries, including the indigenous software sector, serves to strengthen factor conditions in the form of labour skills, and this in turn helps to attract to Ireland further foreign-owned related MNEs which require and help to develop the same type of skills. 


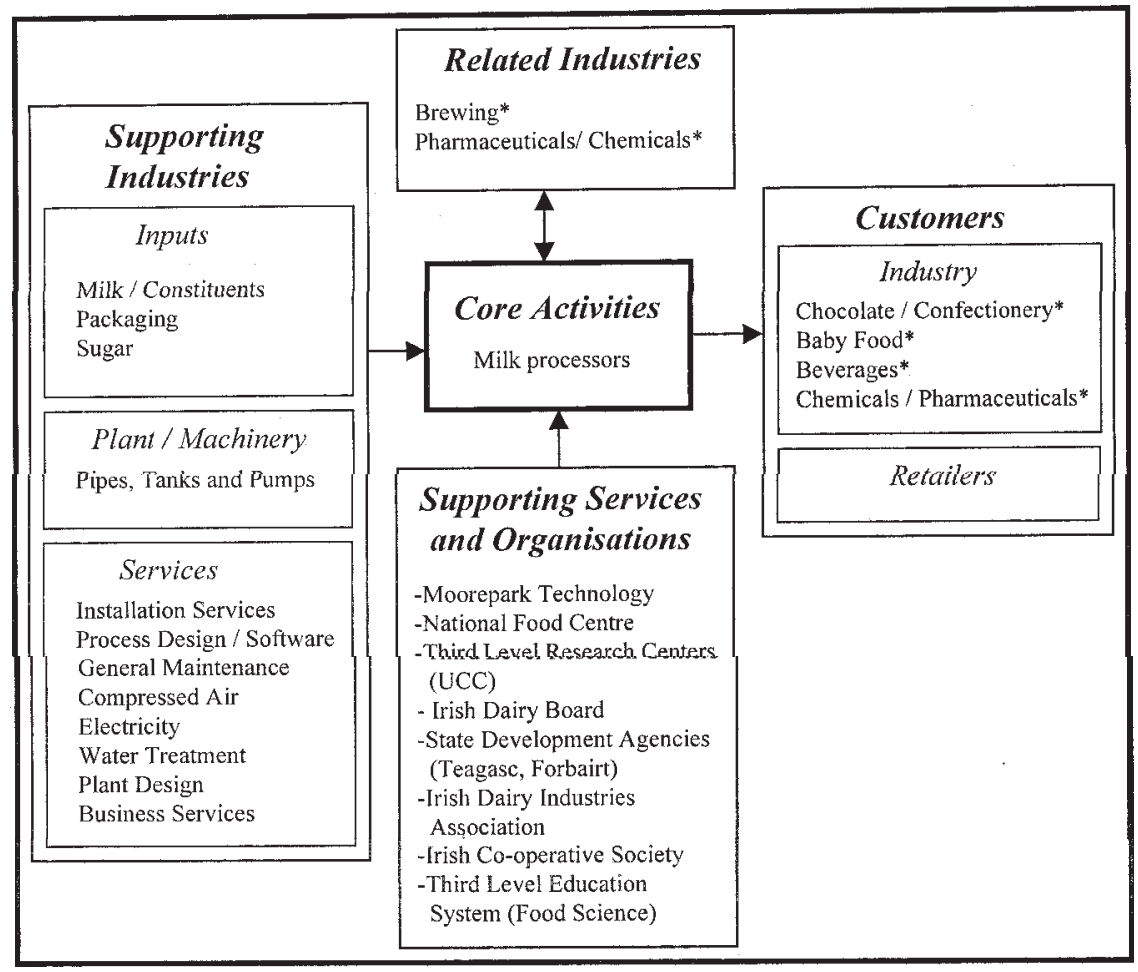

Figure 2. Extended linkages chart of the Irish dairy processing industry. * Denotes mainly foreign owned.

While this grouping of industries has most of the characteristics of a cluster, there are some significant points of divergence from Porter's model. As mentioned above, a noticeable feature of this grouping or cluster is the prominent role of foreign-owned MNEs in Ireland among the related industries and important customer industries. Such connections with foreign MNEs have been quite important in making the local software industry a success. Also, for a substantial minority of firms in the indigenous software industry, domestic demand and domestic rivalry are not relevant influences, whereas customers and competitive rivals outside Ireland do have a significant impact.

In the case of the dairy industry we also identified some significant elements of a cluster and a clustering process, although this was found to a more limited extent than in the software industry. Figure 2 brings together the earlier identified horizontal and vertical linkages of the dairy processing industry in Ireland. The core of the Irish cluster is made up of a relatively large number of indigenous processors, some of which have developed into competitive multinational companies. Downstream we found some forward linkages with a limited number of competitive foreign multinationals located in Ireland. The Irish retailers are also part of the cluster, although they have not developed into global players themselves. Upstream the dairy farmers, who are both suppliers to, and shareholders of, the processing companies, form an important part of the cluster. Apart from farming, the number of competitive suppliers is limited. There are some competitive companies in the area of engineering and process design. However, almost none of these suppliers are active in foreign markets. Finally, two (mainly foreign-owned) industries, brewing and pharmaceuticals, have the potential to enhance the cluster as related industries. These industries use similar technologies and we 
found examples of reciprocal direct interaction and information flow. We also found examples of indirect technology transfer via suppliers, and the movement of technical staff among these industries.

The dairy cluster has a strong geographical dimension. There is evidence of an agglomeration effect where a cluster of processors attracted suppliers, customers as well as the most important dairy related research institutes to the south, the heartland of Irish dairy farming (see Figure 3). This proximity has facilitated information flow within the 'cluster' but it has to

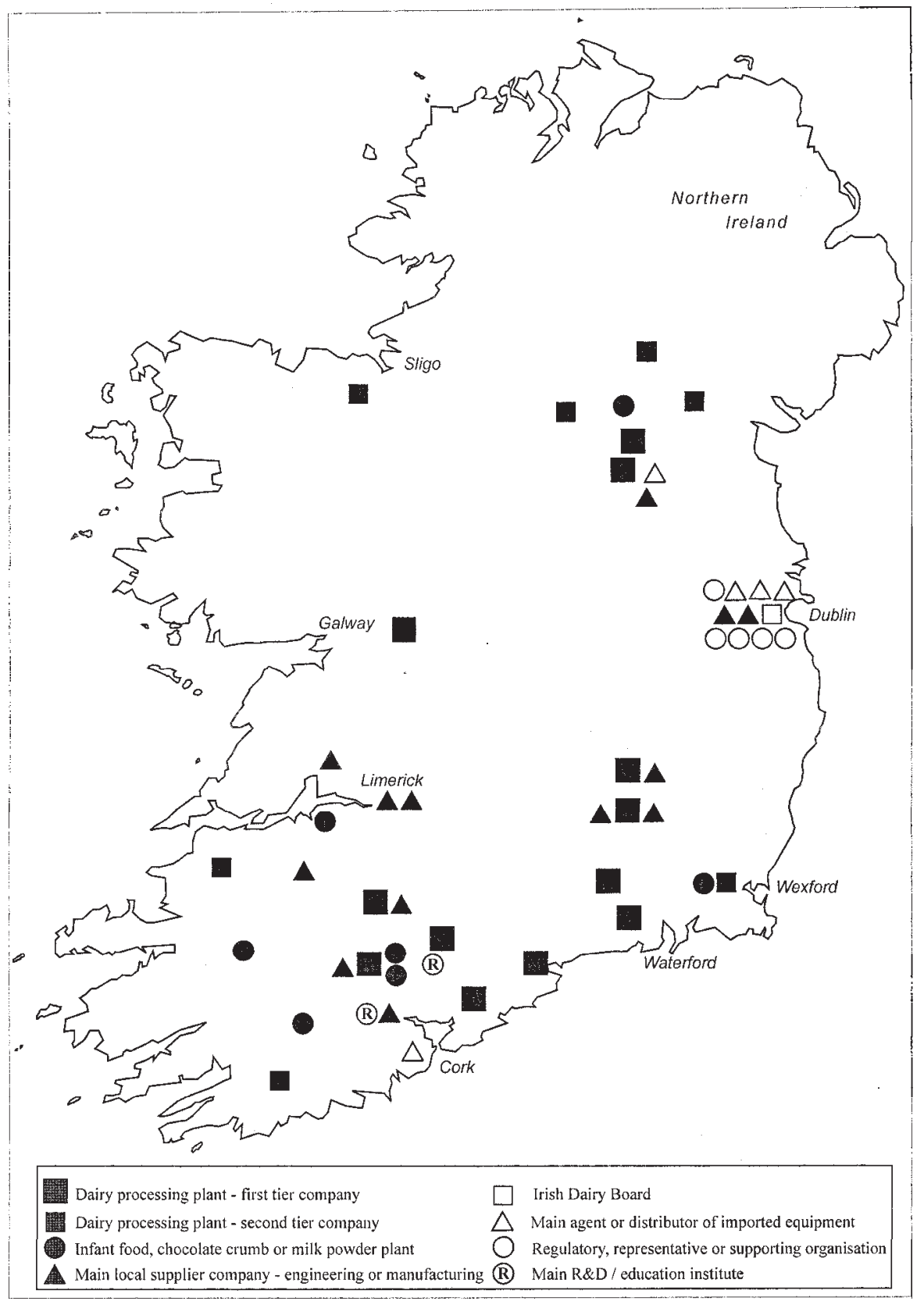

Figure 3. The geography of Ireland's dairy cluster. Source: company interviews. 
be mentioned that processors have equally benefited from relations with customers and suppliers located overseas.

Also in line with Porter's model, there is evidence for the idea that the Irish dairy companies benefit from the systemic effects of a grouping of connected and related industries, operating as a system. Thus, the direct and indirect information flow and knowledge transfer within the grouping of processors, customers, supporting organizations and related industries was seen as a valuable factor. The existence of two high-standard factor-creating research facilities is linked to the presence of a significant number of strong competitors in the dairy processing industry. In addition, educational institutes responded to the strong demand for skilled labour from both the dairy and other processing industries, thus increasing the availability and standards of skilled labour. Indirectly, the strong competition for raw milk supplies had a positive effect on processing innovation and international expansion of the dairy processors. The existence of a grouping of milk processors in Ireland has also affected demand conditions in the Irish market. The availability of (primary processed) milk formed an important attraction for a number of multinational companies to set up production facilities in Ireland. In turn, these companies increased the demand for skilled labour, the sophistication of production facilities and the standards of the Irish processing industry in general. Finally, there is some evidence that the presence of the milk processing sector, and other 'related' processing industries, led to the formation of new firms and skills in the supply sectors.

It is clear nevertheless that on a number of important points this falls short of being a true cluster in Porter's sense of the term. In particular, the dairy 'cluster' is limited in scale and scope, with relatively few competitive suppliers apart from suppliers of milk. Furthermore, most of the important downstream and related industries consist mainly of foreign-owned MNEs. These multinational customers appear to be embedded in the local production structure and for most Irish dairy companies the links with these MNE customers in Ireland have played a positive role.

The music industry is not part of a cluster of competitive industries in Ireland which sustains the competitive advantage of the industry. Figure 4 shows the components of the music industry present in Ireland. Of these, only the major Irish artists are clearly internationally competitive and successful. If they are contracted to a record company in Ireland, it is most likely to be a subsidiary of a foreign-owned MNE that is strongly dependent on decisions taken by the parent company outside the national context. Although most of the important supplier industries are present to some degree, the majority of enterprises are small and few are commercially viable. While there is a well-developed group of organizations representing the music industry, an infrastructure of intermediary bodies to support the industry is still poorly developed in Ireland. Virtually all successful Irish artists go abroad, not only to sign record contracts, but also to avail of many of the supplier inputs and supporting services. Downstream, domestic demand is relatively sophisticated although mainly shaped by influences which are controlled by companies with their home base in the UK or the US. The retailers are all foreign-owned. Finally, to some extent the music industry is related to the tourism industry through the provision of live music and by creating an attractive 'brand'.

Although most of the relevant companies and bodies are spatially concentrated within the greater Dublin area, it is clear that the 'home base' concept is of little relevance to the competitiveness of the Irish artists. Artists can be successful without necessarily tapping into the Irish industry or related industries in a significant way. For other elements of the Irish music industry which cannot as yet be considered very competitive, links to other markets are at least as important, if not more important than linkages within Irish national boundaries. Contrary to the situation in the software and dairy 'clusters', in the music industry the impact of the presence of subsidiaries of foreign MNEs has been rather limited. Their presence did 


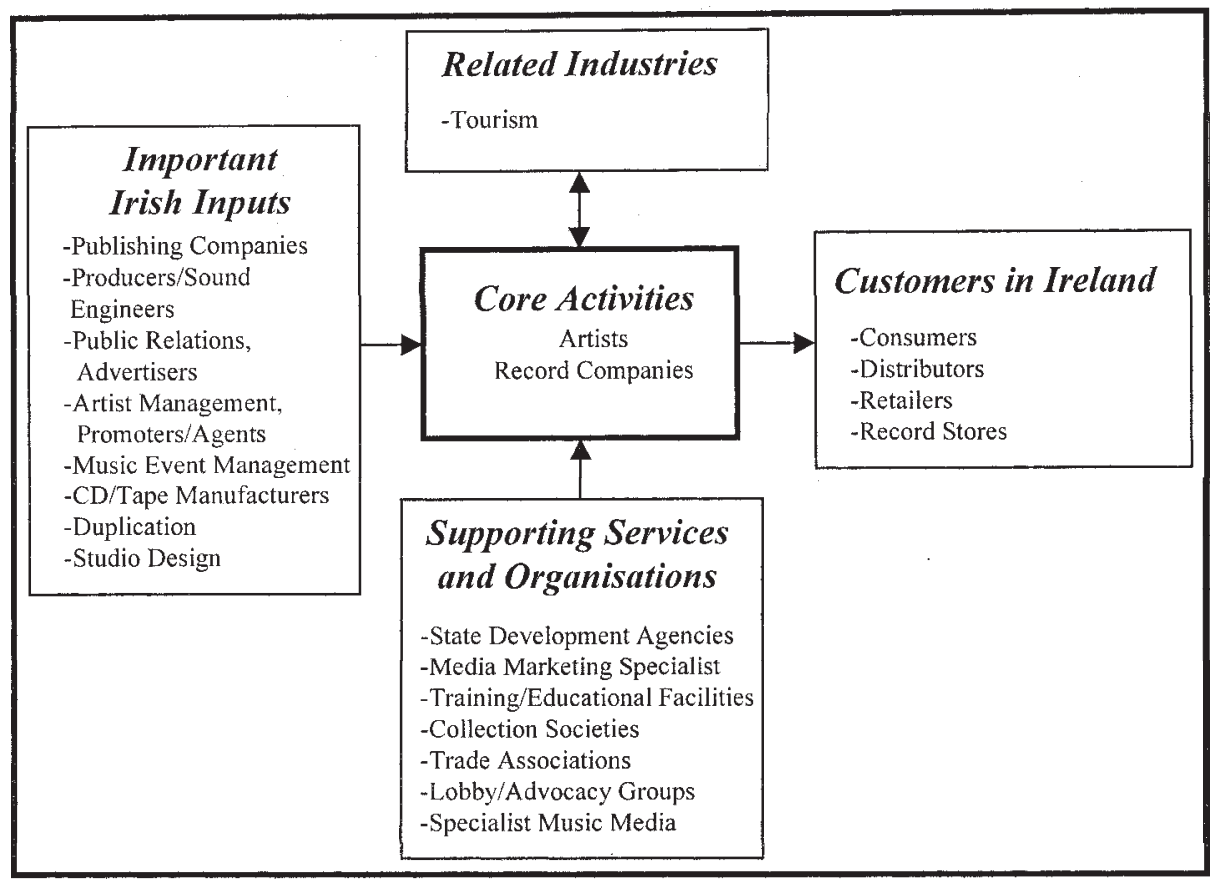

Figure 4. Components of the popular music industry in Ireland.

contribute to an expansion of the domestic market and stimulate local factor creation. However, these subsidiaries show a low level of local 'embeddedness'. They therefore have had relatively little effect on artist development or on growth or upgrading of the supplier and service industries. Similarly the interaction with indigenous record companies has been limited.

However, even in the music industry we identified beneficial systemic effects of a concentration of connected and related companies and the interactions between them. The brand reputation of Ireland as a centre for popular music is partly an outcome of the international success of a number of Irish stars and is also likely to be a contributing factor in their decision to continue to live in Ireland. The increasing activity in record companies and supplier industry segments is likely to have been influenced by this reputation, while the development of industry institutional structures, including trade associations and advocacy groups, is likely to be at least in part an outcome of this growth in activity. The geographic concentration of these enterprises and activities within the greater Dublin area has facilitated the flow of information and the development of explicit industry strategies in relation to some factor creation.

Overall then, we do not find evidence of fully developed 'clusters' of the same type and scale described by Porter. But different elements of Porter's model do prove relevant to the explanation of the performance of the three indigenous sectors. The findings show that companies in the three industries benefit from being part of some form of wider grouping of connected or related companies and industries in Ireland and from interactions between them. Furthermore, various aspects of the four determinants of competitive advantage are at work, reinforce each other, and can be seen to contribute appreciably to the competitive advantage of the industries. 
However, our study also provides substantial support for some of the critiques of Porter's model reviewed earlier, particularly those which question the importance of the 'home base' to small open economies like Ireland. At different geographical scales, all three case study industries are spatially concentrated within Ireland. But Porter's emphasis on the special importance of significant customers, competitors and suppliers which are located within national boundaries is not always reflected in our case studies. For at least some parts of the three industries which we have studied, some of the most important factors, influential customers, competitors or suppliers are located abroad. A second point of divergence from the general thrust of Porter's model arising from our findings is the role played by foreign MNEs in fostering competitiveness. For substantial parts of the three industries, the important links with related, supporting or customer industries are with foreign-owned MNEs in Ireland, rather than with Irish indigenous companies. These foreign-owned MNEs can have an important and positive influence on indigenous industry.

\section{Conclusions and Policy Implications}

As was noted above, Irish indigenous industry includes very few clear and convincing examples of sectors which are successful and competitive, and hence two of our three case study industries cannot really be regarded as clearly competitive. This presents something of a complication in drawing out general conclusions and implications from our findings. Porter aims to model the determinants and processes that are responsible for generating competitive industries. Therefore, the preferred methodology would have been to examine some unequivocally competitive Irish sectors, to consider whether the operation of Porter-style clusters has been important in accounting for their competitive success, and then to draw conclusions on the validity of the model and its relevance in the Irish context. As it is, however, our findings are not amenable to such straightforward interpretation.

Two different broad interpretations could be suggested by our complex set of findings, but consideration of both of these leads to the conclusion that Irish industrial policy does not need to be focused strongly on developing the type of industry clusters described in Porter's model. ${ }^{8}$

The first possible interpretation which might be suggested is to regard the results of our case studies as consistent with the view that Porter's clusters are usually the way to go, for a successful process of economic development. In other words, the general validity of Porter's model applies to most successful industries in most countries. Support for this interpretation can be found if we look beyond the Irish situation, where there is considerable evidence for the proposition that successful industries usually are part of competitive clusters, arising from all the research in a range of different countries reported in Porter (1990). Further studies undertaken by research teams in other countries, albeit with varying degrees of disagreement on some points and both additions to and qualification of others, also broadly support his findings on the importance of clusters for competitive advantage.

The fact that we do not find Porter-style clusters among our case studies could then be explained by the failure of at least two of these industries to meet Porter's definition of competitiveness. To the extent to which clustering is evident, it is in direct proportion to the varying degrees of competitiveness found between the three industries examined. Thus, software which is the most unambiguously competitive is also the most clustered. The more general scarcity of strong sectors or clusters among the rest of Irish indigenous industry could be seen as consistent with its weak long-term competitive performance over many decades.

In response to this interpretation, however, we would have to refer to the experience of Irish indigenous industry as a whole in recent times, as outlined above. Despite the fact that Irish indigenous industry has few clearly competitive sectors, and hence does not appear to have significant examples of Porterian clusters, it has been performing relatively well since 


\section{Paula Clancy et al.}

about 1987. The rate of output growth in indigenous industry has been about twice as high as the industrial growth rate of the EU or OECD. Employment in indigenous manufacturing increased by $9 \%$ in 1988-1997, in contrast to the significant decline in manufacturing employment which was occurring in the EU and the OECD in the same period. In addition, the proportion of indigenous industrial output which was exported increased from $26.6 \%$ in 1986 to $35.9 \%$ by 1995, and the growth of the exports of Irish indigenous industry was faster than the growth of industrial exports from the EU or the OECD. Thus, this has probably been the most successful period to date for the development of internationally competitive Irish indigenous industries.

To a considerable extent, this recent growth has occurred in small or medium-sized enterprises, spread quite widely across a range of sectors, with the fastest growth occurring in sectors which looked relatively small and undeveloped to begin with and which are still not particularly strong. In addition, part of the growth of indigenous industry has occurred in a limited number of larger more prominent companies, in sectors which themselves still look rather insubstantial. Thus, the growth has not come from a context of strong sectors and clusters. This experience shows that progress in Irish indigenous development has been possible, starting from a relatively weak and unimpressive position, without having very strong indigenous sectors or clusters of the type which Porter suggests are generally required for competitive success. Consequently, even if it is true that Porter's model of cluster development applies to most industries in most countries, recent experience suggests that it has not applied in any rigorous manner in the small and very open economy of Ireland. It may turn out that this was an exceptional experience, with growth occurring from a low starting point, and it is possible that it will prove difficult to sustain Irish indigenous growth over the longer term unless stronger Porterian clusters emerge. But developments to date appear to offer little firm support for this view.

The second possible interpretation of our results is that critics of Porter are right. This follows from those findings of our study which attribute the sources of success and competitiveness of our three case-study industries to factors which in some important respects do not conform to Porter's model of the cluster. This interpretation suggests that his theory has at best limited applicability, e.g. it may be confined to large mature manufacturing economies, and even then may require substantial modification. In particular, its relevance to Small open economies like Ireland is seriously open to question, particularly those aspects of the model which stress the importance of the 'home base' and which give limited credence to the potentially positive role played by foreign direct investment in fostering competitiveness.

In conclusion, the question posed in this study is should Irish industrial policy be focused on the development of clusters of related industries, according to the model developed by Porter. From the evidence of our study the answer must be negative. Porter is a good starting point to identify parameters in which Irish competitiveness can be addressed, but given the serious questions raised about the general applicability of the model, and given the specific nature of Irish economic/industrial conditions, it is necessary to search for an alternative model for Irish industrial development.

\subsection{Policy Implications}

The primary concern of this study was to examine the relevance of one particular model, that of Porterian clusters, which had been put forward as a major plank of Irish industrial policy. It is another task to determine what the alternatives should be. While we are not in a position to provide a blueprint for such an alternative model, our findings do suggest a number of its elements. 
Support for existing policies. First, it is worth bearing in mind that some Irish industrial policies, which aim to assist the development of indigenous industry, would not be in accord with the Porterian model but have nonetheless been meeting with some success. The policies concerned have focused most on the further development of companies with a reasonable track record and good prospects for growth in international markets. Thus, existing policies include an element of focus on building on the strong, although this relates to building on strong companies more than strong sectors or clusters. In addition, Irish industrial policy has also included an important component which focuses on attracting foreign MNEs to Ireland. These policies are in some contrast to Porter's thinking which, with its key emphasis on clusters of home-base industries, would probably see rather little merit in aiming to develop individual companies or in attracting foreign MNEs - at least not in the context of the more advanced stages of economic development.

Support for the emergence and development of groupings of connected companies and industries. Second, our conclusions do suggest that it would commonly be advantageous for Irish industrial policy to include a somewhat more explicit element of building on strong indigenous sectors or strong groups of connected companies or industries. Such an approach would seek to foster groupings which could differ from Porter's concept of the cluster in some important respects. These would include a recognition that foreign demand, competition and suppliers can sometimes be as relevant as domestic demand, competition and suppliers, and recognition of the positive role often played by foreign MNEs in Ireland. The precise form of grouping of connected companies, and the geographical scale which is desirable and feasible, would probably vary case by case.

In order to foster the development of groups of connected or related companies or industries, it would be necessary to identify relatively promising opportunities for such development. Then the State development agencies should be particularly receptive to assisting project proposals coming from companies which would help to develop the groupings concerned. The identified opportunities for developing groupings should also influence IDA Ireland in targeting the overseas MNEs which it seeks to attract into Ireland. At the same time Enterprise Ireland (the principal agency responsible for supporting indigenous development) should encourage suitable companies to expand in the groupings concerned, with the offer of significant assistance to do so. The development of interrelated groupings could also be facilitated by providing appropriate geographically concentrated industrial space in complexes designed for specific industries. Such action would not be a matter of State agencies simply deciding which industries and companies to develop, since there would be an essential element of self-selection, with the companies concerned making their own decisions about whether to participate and how to do so. It should also be stressed that we are not arguing that all industrial policy efforts should be focused on developing groupings of connected or related industries or companies. The industrial development agencies should continue to be open to assisting other worthwhile projects.

Attraction of MNEs with certain characteristics. A third element is continuation of efforts to attract foreign MNEs to Ireland, but with a special interest in certain types. Our case studies offered indications about the type of foreign enterprise that is most influential in stimulating further development of related indigenous industries. Ideally, the most beneficial types of MNEs from abroad have several desirable characteristics. They should employ a significant proportion of highly skilled labour, particularly employees engaged in R\&D. They should be willing to purchase inputs of goods and services which would be produced by firms in Ireland. And there should be a match between these conditions and the type of industries which can realistically 
be developed by Irish firms. For example, the skills which the foreign MNEs help to develop should be skills which could be beneficial to the development of Irish firms in industries which are realistically accessible to them - not skills which can only be used, for example, in very large-scale industries or in industries which present other very substantial barriers to entry.

Technology focus. Fourth, a technology focus is necessary, but with a particular emphasis on acquiring and further developing technology from abroad. Enright's (1992, p. 25) principal suggestion on how to foster further development of a relatively successful cluster is to "invest in developing the major technologies and capabilities that cut across the industries in the cluster. Such investments will have the greatest leverage in deepening and broadening the cluster. They should include development of indigenous technology as well as acquiring best practice technology from abroad." Although our concern is to build groups of connected companies or industries which could be quite different to Porter's clusters, for the most part we agree with Enright's suggestion, although perhaps with a different emphasis. We have some reservation about how Enright's idea of investing in 'the major technologies' might be interpreted. A small country like Ireland cannot make very large-scale investments in some of the major technologies. Hence we would put the emphasis on acquiring foreign best practice technology and focusing Ireland's own R\&D efforts on developing new or specialized applications of technology.

Support for cooperative alliances between companies. Fifth, policies to foster the development of groupings of companies or industries should include support for cooperation and alliances between relevant companies. Such cooperation can happen spontaneously, of course. But there are also many examples in the literature on industrial districts and other types of groupings where institutional interventions, public or private, have functioned to facilitate cooperative structures and the development of infrastructure for regulating cooperation (Cooke \& Morgan, 1998; Staber, 1996a). Steps to support cooperation and alliances can be taken by local authorities as well as national development agencies. In Ireland, an example of such action is the National Software Directorate, which has implemented its own forms of assistance to the process of building cooperation and alliances. In the dairy industry, the Irish Dairy Board is an example of how firms can be helped to cooperate for export marketing purposes. In the music industry, transnational cooperative linkages are seen to be important but small local companies are constrained by a lack of resources in developing these to the extent necessary. There are industry calls for the establishment of an Irish Music Board to devise policies for developing the industry as a whole.

\section{Notes}

1. Selectivity in the sense of focusing on targeted indigenous sectors was not so prominent a feature, although there were certain examples of sectoral studies and indicative plans.

2. For a more complete review of critiques of Porter's model, see Clancy et al. (1998).

3. For example, the Irish-sourced share of materials used by the predominantly foreign controlled 'computer equipment' sector increased from $7.6 \%$ in 1989 to $19.4 \%$ in 1993 (Crowley, 1996).

4. For a more detailed description of the selection process and applied statistical methodology, see Clancy et al. (1998)

5. In Porter's (1990) approach to identifying the relatively competitive industries in a country, predominantly foreign-owned industries are generally excluded from consideration because he does not regard these as reflecting the nation's own competitive advantage. As our own study aimed to focus on indigenous industry per se, we excluded mainly foreign-owned sectors as possible case studies, but this was not intended to imply any a priori judgement about the role or importance of such sectors. 
6. For details of the findings on the three case study industries, see the separate sectoral reports by O'Connell et al. (1997), Clancy and Twomey (1997) and O'Gorman et al. (1997).

7. Moorepark Technology is a non-profit joint venture company between Teagasc and the major Irish Dairy Processing companies with the objective to facilitate product development for the Irish dairy and food ingredients industry. The company operates a dairy processing plant for pilot research.

8. Note that our position on the relevance of Porter's model should be seen in the light of our adherence to a strict definition of 'clusters' and 'clustering'. Thus, Cooke (1998) takes a more positive position as regards the applicability of the model to the Irish economy, but his concept of clusters does not preclude a significant role for foreign multinationals.

\section{References}

ABN.AMRO (1996) Raising The Value-Added: A Strategic Review of the Top 15 European Dairy Manufacturers. Dublin.

BeLLAK, G.J. and Weiss, A. (1993) A note on the Austrian diamond, Management International Review, 33(Special issue), pp. 109-118.

Clancy, P. and Twomey, M. (1997) Clusters in Ireland: The Irish Popular Music Industry: An Application of Porter's Cluster Analysis, Research Series Paper No. 2. Dublin: National Economic and Social Council.

Clancy, P., O’Malley, E., O'Connell, L. and Van Egeraat, C. (1998) Culliton's clusters: still the way to go?, in Sustaining Competitive Advantage: Proceedings of NESC Seminar, pp. 15-47, Research Series. Dublin: National Economic and Social Council.

Clarke, A. (1995) Software Support Programme: Final Report. Dublin: EU Structural Funds Operational Programme for Industrial Development Evaluation Unit.

CoE, N. (1997) US transnationals and the Irish software industry: assessing the nature, quality and stability of a new wave of foreign direct investment, European Urban and Regional Studies, 4, pp. 211-230.

Cooke, P. (1995) Innovative regional clusters: the automotive and electronics industries in Wales, Paper presented at conference on Regional Innovation Systems: Designing for the Future. Stuttgart: Centre for Technology Assessment.

CoOKe, P. (1998) Enterprise support policies in dynamic European regions: policy implications for Ireland, in Sustaining Competitive Advantage: Proceedings of NESC Seminar, pp. 68-88, Research Series. Dublin: National Economic and Social Council.

Cooke, P. and Morgan, K. (1998) The Associational Economy: Firms, Regions and Innovation. Oxford: Oxford University Press.

Crowley, M. (1996) National Linkage Programme. Dublin: Industry Evaluation Unit.

Dalum, B., Jorgensen, U., Moller, K. and Valentin, F. (1991) Porter og den erhvervpolitiske debat, Samfundsokonomen, 7, pp. 33-41.

Department of Industry and Commerce (1987) Review of Industrial Performance 1986. Dublin: Stationery Office.

Dunning, J.H. (1992), The competitive advantage of countries and the activities of transnational corporations, Transnational Corporations, 1, pp. 135-168.

EnRight, M.J. (1992) Why local clusters are the way to win the game, World Link, July/August, pp. 24-25.

Goodbody Stockbrokers (1995) Food Retailing in the Republic of Ireland. Dublin.

Harte, L.N. (1995) Creeping Privatisation of Irish Co-operatives: A Transaction Cost Explanation. Paper presented at the EIASM Workshop on Industrial Changes in the Globalised Food Sector, Brussels, 27-28 April.

Hudson, R. (1997) Regional futures: industrial restructuring, new high volume production concepts and spatial development strategies in the new Europe, Regional Studies, 31, pp. 467-478.

Industrial Policy (1984) Government White Paper. Dublin: Stationery Office.

Industrial Policy Review Group (1992) A Time for Change: Industrial Policy for the 1990s. Dublin: Stationery Office.

Jacobs, D. (1995) Alle clusters groot en klein, in D. Jacobs and A.P. DE MAN (Eds) Clusters en Concurrentiekracht: Naar een Nieuwe Praktijk in het Nederlandse Bedrïfleven. Alphen aan den Rijn: Samsom Bedrijfsinformatie bv. 


\section{Paula Clancy et al.}

LaIng, D. (1996) The economic importance of music in the European Union, in European Music OfFICE (EMO) Music in Europe. Brussels.

MorRIs, J. (1989) Japanese inward investment and the 'importation' of sub-contracting complexes: three case studies, Area, 3, pp. 269-277.

National Economic and Social Council (1982) Policies for Industrial Development: Conclusions and Recommendations, Report No. 66. Dublin: National Economic and Social Council.

Negus, K. (1992) Producing Pop: Culture and Conflict in the Popular Music Industry. London: Edward Arnold.

O'Connell. L., Van Egeraat, C. and Enright, P. (1997) Clusters in Ireland: The Irish Dairy Processing Industry: An Application of Porter's Cluster Analysis, Research Series Paper No. 1. Dublin: National Economic and Social Council.

O’Donnell, R. (1997) International competitiveness in the context of peripheral regions, in B. Fynes and S. Ennis (Eds) Competing from the Periphery. Dublin: Oak Tree Press.

O'Donnell, R. (1998) Post-Porter: exploring policy for the Irish context 'sustaining competitive advantage', in Sustaining Competitive Advantage: Proceedings of NESC Seminar, pp. 48-67, Research Series. Dublin: National Economic and Social Council.

O'Donnellan, N. (1994) The presence of Porter's sectoral clustering in Irish manufacturing, The Economic and Social Review, 25, pp. 21-23.

OECD (1995) Education at a Glance: OECD Indicators. Paris: OECD, Centre for Educational Research and Innovation.

O'Gorman, C., O’Malley, E. and Mooney, J. (1997) Clusters in Ireland: The Irish Indigenous Software Industry: An Application of Porter's Cluster Analysis, Research Series Paper No. 3. Dublin: National Economic and Social Council.

O'Malley, E. (1989) Industry and Economic Development: The Challenge for the Latecomer. Dublin: Gill \& Macmillan.

O'Malley, E. (1998) The revival of Irish indigenous industry 1987-1997, in T.J. BAKER, D. Duffy and F. Shortall (Eds) Quarterly Economic Commentary, April. Dublin: The Economic and Social Research Institute.

O'Malley, E., Kennedy, K.A. and O'Donnell, R. (1992) The Impact of the Industrial Development Agencies, Report to the Industrial Policy Review Group. Dublin: Stationery Office.

PA Consulting Group (1996) Developing Ireland's Opportunity in Dairy Ingredients: Sector Study on Future Customer Expectations. Report to The Irish Food Board, Dublin.

Peck, F. (1990) Nissan in the north-east: the multiplier effects, Geography, 75, pp. 354-357.

Penttinen, R. (1994) Summary of the Critique on Porter's Diamond Model: Porter's Diamond Model Modified to Suit the Finnish Paper and Board Machine Industry, ETLA Discussion Paper No. 462. Helsinki: The Research Institute of the Finnish Economy.

Porter, M.E. (1990) The Competitive Advantage of Nations. London: Macmillan.

Porter, M.E. (1998) Clusters and the new economics of competition, Harvard Business Review, NovemberDecember, pp. 77-90.

Rugman, A.M. and D'Cruz, J.R. (1993) The 'double diamond' model of international competitiveness: the Canadian experience, Management International Review, 33(Special issue), pp. 17-39.

STABER, U. (1996a) Networks and regional development: perspectives and unresolved issues, in Business Networks: Prospects for Regional Development. Berlin and New York: Walter de Gruyter.

Van Grunsven, L. and Van Egeraat, C. (1999) Achievements of the industrial 'high-road' and clustering strategies in Singapore and their relevance to European peripheral economies, European Planning Studies, 17, pp. 145-173. 